their ensuing revels. When not too much engrossed, they display the instinct shared with so many other strongly flying members of their order, and, on the approach of danger, clamber to the petal's edge and seek safety by dropping to the cover that lies below.

The Caltha seems to be an unrecorded food-plant for the genus, though hardly a surprising one in view of its evident adaptability and its environmental association with the skunk cabbage, the resort of certain others of its component species.

So far as they have come under the writer's observation, the males of $D$. emarginata in this neighborhood are uniformly purplish or bluish-black, while the females are never like them in colour, but vary through shining olivaceous green, the shade most commonly occurring, to brassy and rich bronze. If these colour distinctions hold constant with the beetles from other localities, we have here secondary sexual characters which are worthy of note.

\title{
A NEW BRACONID OF THE GENUS MICRODUS FROM CANADA.
}

BY C. H. RICHARDSON, JR., FOREST HILLS, MASS.

Among a number of parasitic hymenoptera reared from the Bud Moth (Tmetocera ocellana Schiff.), at the Dominion Entomological Laboratory, Bridgetown, Nova Scotia, by Mr. G. E. Sanders, there is a Braconid belonging to the genus Microdus which appears to be new. Since it is desired to refer to this species in the near future, Dr. Hewitt, Dominion Entomologist has asked me to describe it at the present time.

\section{Microdus ocellance, sp. nov.}

Description of the type (female): Length $5 \mathrm{~mm}$. Wing $4 \mathrm{~mm}$. Ovipositor about $5 \mathrm{~mm}$. Head, thorax and abdomen black, refulgent; palpi pale fulvous; fore and middle legs pale fulvous, with the apical joints black; hind legs pale fulvous except for the black coxæ, the black apical annuli on the tibiæ, the darkened distal ends of the first tarsal joints and the complete darkening of the succeeding joints. A large fulvous spot covering the first and second abdominal segments ventrally. Pubescence light. Wings slightly infuscated, iridescent; stigma black. Head slightly wider than thorax, less than three times as wide as thick; clypeus slightly produced; clypeal foveæ large, each equaling an ocellus in size; face 
punctuiate, pubescent; vertex, occiput and genæ sparsely punctulate and pubescent. Antennæ 42 -jointed, stape and pedicel longer than the first joint of the flagellum; joints of flagellum subequal. Mesonotum punctulate, with deep punctate parapsidal grcoves which meet posteriorly. Scutellum punctulate flatly convex; anterior depression of scutellum with four deep umbilicate punctures. Metanotum rugose-punctate; metathoracic spiracles oval, slightly longer than wide. Mesopleuræ sparsely punctulate and pubescent with a curved punctured line just below the tegulæ; a single postmedian fovea and a longitudinal row of umbilicate punctures below this. Metapleuræ more densely punctulate and pubescent. First segment of the abdomen deeply striated longitudinally; the second segment weakly and irregularly aciculated with a median transverse depression; remaining segments smooth, shining.

Type of No. 4001d, July 28, 1912; in Coll. Div. Ent., Ottawa.

Type locality.-Kentville, Nova Scotia, Canada.

Paratype $(q)$ agrees essentially with the type.

This species is related to Microdus earinoides Cresson resembling it in size and colour, but differing in the sculpture of the abdomen,the possession of black hind coxæ and the extent of the black on the hind tibiæ as well as the quite distinctly infuscated wings. It is also very similar to Microdus nigricoxis Provancher, but only the hind coxæ are black and the basal segment of the abdomen is striated, not rugose. Acknowledgments are due Mr. C. T. Brues for aid in looking up the literature.

\section{A SUCCESSFUL MOVE}

Recently I had occasion to move my entire collection of over 200 well-filled boxes of Hemiptera from Buffalo, N. Y., to San Diego, Calif., and on unpacking them here was surprised to find that not a single specimen had been damaged. The boxes were packed in straw in two large willow pottery crates and were shipped by freight through one of the household shipping agencies. However, they had to go through two storage warehouses and be twice reshipped before starting on their long ride which speaks well for the packing. I received my instructions for packing from Dr. E. D. Ball and will gladly pass it on to any one contemplating a similar move.-E. P. Van Duzee, 4020 Ivy St., San Diego, Calif. 


\section{$2 \mathrm{BHL}$ Biodiversity Heritage Library}

Richardson, Charles H. 1913. "A new braconid of the genus Microdus from Canada." The Canadian entomologist 45, 211-212. https://doi.org/10.4039/Ent45211-7.

View This Item Online: $\underline{\text { https://www.biodiversitylibrary.org/item/22231 }}$

DOI: https://doi.org/10.4039/Ent45211-7

Permalink: https://www.biodiversitylibrary.org/partpdf/27093

\section{Holding Institution}

MBLWHOI Library

\section{Sponsored by}

MBLWHOI Library

\section{Copyright \& Reuse}

Copyright Status: NOT_IN_COPYRIGHT

This document was created from content at the Biodiversity Heritage Library, the world's largest open access digital library for biodiversity literature and archives. Visit BHL at https://www.biodiversitylibrary.org. 